\title{
Re-Examination of Servicescape Model: Food Expectation and Patronage to Macau's Restaurant from Chinese Visitors' Perspectives
}

\author{
Grace Suk Ha Chan, Junya Li \\ Faculty of International Tourism and Management, City University of Macau, Macau SAR, China \\ Email: gracechan@cityu.mo, 970805184@qq.com
}

How to cite this paper: Chan, G. S. H., \& Li, J. Y. (2020). Re-Examination of Servicescape Model: Food Expectation and Patronage to Macau's Restaurant from Chinese Visitors' Perspectives. Journal of Service Science and Management, 13, 470-497. https://doi.org/10.4236/jssm.2020.133032

Received: April 14, 2020

Accepted: May 19, 2020

Published: May 22, 2020

Copyright ( 2020 by author(s) and Scientific Research Publishing Inc. This work is licensed under the Creative Commons Attribution International License (CC BY 4.0).

http://creativecommons.org/licenses/by/4.0/

\begin{abstract}
The appearance of the physical surrounding which potentially effect to visitors their expectations of the food. Service environment under the right design may lead to visitor patronage the restaurants. Restaurant owners need to understand how to make use of service environment and affect buying behavior. Servicescape model had been well discussed over the last two decades, which provide a road map for service provider how to adopt service environment in provide customer service expectation. The purpose of this paper is to expand the servicescape model and re-exam service environment which affect their food expectation and patronage to local restaurant in Macau. Hope to make further suggestion to the industry. The rationale of this study aims to examine under the physical dimensions, Chinese visitors what is their food expectation and patronage to restaurant. Previous scholars had adopted various studies in relate to service environment by using the servicescape model, however, limited study which conduct a re-examination the traditional elements under the servicescape and Chinese their buying behavior. The study adopted qualitative research and provided 30 Chinese visitors' their expectations of the local restaurants, from the service environment which may lead to have different expectation and their buying decision. In-depth interview with semi-structure questions were provided in the study. Discussion made by the interviewees demonstrated visitors' expectations of the service environment not limited to the traditional elements from servicescape. Result will be discussed and provided an implication to the industry how it can improve the service environment and stimulate the visitors buying behavior.
\end{abstract}

\section{Keywords}

Chinese Visitors, Food Expectation, Patronage, Servicescape, Service 


\section{Introduction}

\subsection{Research Background}

With a well-known branding of "The Historic Centre of Macau" was added to the UNESCO world heritage list in 2005, promoting the culture and heritage in the city. Adopted east meet west strengthened Macau's historical appeal as well as giving the city a facelift as a diversified tourism destination encompassing heritage offering with gaming entertainments (Vong \& Ung, 2010). Macau has been designated as the UNESCO creative city of Gastronomy at 2017 and the government aims to preserve and revive the city of gastronomy (Yu \& Sun, 2019). It is worthwhile for investigate under the creative of gastronomy city, does the restaurant can create value in the physical setting and stimulate visitors' food expectations and their buying decision? Based on Bitner (1992) under the servicescape framework provided implication to marketers, the three dimensions include ambient conditions; spatial layout and functionality and signs, symbols, artifacts. The servicescape shapes the expectations of the customers and also their satisfactions (Harrell, Hutt, \& Anderson, 1980; Bitner, 1990). However, a servicescape not only influences customer perceptions of service functions and service quality, but more subtly, also influences the meanings a customer draws from the many intangible, contextual and symbolic elements of a service (Bitner, 1990). For instance, some environmental cues can suggest that a restaurant is either an elegant sit-down restaurant or a fast-food (Bitner, 1992), or also recognize it with special techniques, and it can increase the customer patronage behavior and provide positive experience (Chua, Othman, Boo, Abkarim, and Ramachandran, 2010).

Service environment apart from affect customer satisfaction also service environment potential affect customer response. Since customers interact with service environment and personal during the consumption experience, understand customers' affective response becomes crucial (Szymanski \& Henard, 2001; Wirtz et al., 2000; Zins, 2002). Environmental psychology suggests that customers' reactions to the tangible physical environment may be more emotional than cognitive, particularly when involving hedonic consumption (Wakefield \& Blodgett, 1999) which address the multisensory, fantasy and emotive aspects of product use (Hirshman \& Holbrook, 1992). If a consumer spends periods of time experiencing the service environment, they will pursue more hedonic purposes.

\subsection{Problem Statement}

A large number of studies which focus in gambling and MICE industry in Macau (Lam, Chan, Fong, \& Lo, 2011; Ho, Lam, \& Lam, 2019; Siu, Wan, \& Dong, 2012), as (Figure 1) demonstrated catering and food consumption of the visitor 
base on the spending allocated one of the high percentage sectors in Macau. Most of the visitors spent primarily on shopping at $45.4 \%$ of total and local food products consumption comprised the biggest part in shopping sector. Food and beverage ranked the 3rd in visitor spending structure and accounted for $20.9 \%$. Table 1 also demonstrated the year-on-year growth rate of food and beverage sector, a jump of $16.4 \%$ over 2016 and close to $18 \%$ growth rate of gambling. This table also indicated the importance of food and beverage for visitors' travel. Although gambling as the biggest destination attraction for visitors, the food and beverage sector should not be ignored.

Overall the data demonstrate the importance of food and beverages industry. Many previous scholars (Chan, Wan, \& Tam, 2019; Wai Lai, 2019) only focused on hotel industry, while catering industry provides high importance in service community. Catering industry generates high employment in the community, entailing lots of job opportunities, better skills, and experiences for employees. Table 2 shows that from 2012 to 2016, the number of persons engaged catering industry increased by 21,987 to 32,551 , which means more and more employees

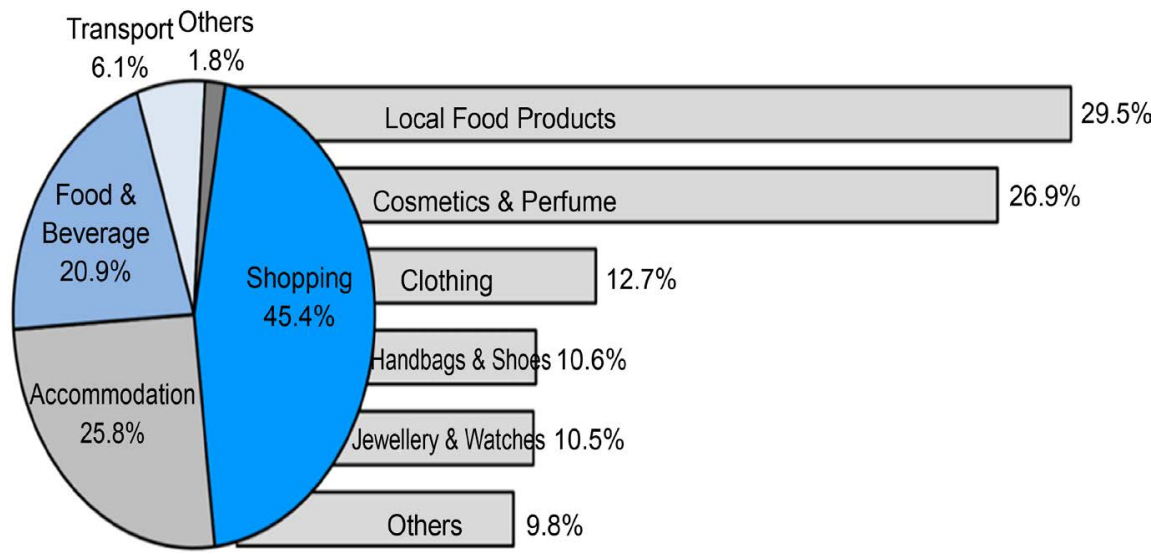

Figure 1. Structure of visitor spending. Source: Macau Statistics and Census Service, 2018.

Table 1. Direct tourism consumption of visitors.

\begin{tabular}{|c|c|c|c|c|c|c|c|c|}
\hline \multirow{3}{*}{$\begin{array}{l}\text { Tourism Goods } \\
\text { \& Services }\end{array}$} & & & & & & & \multicolumn{2}{|c|}{ Million MOP } \\
\hline & \multicolumn{3}{|c|}{2017} & \multicolumn{3}{|c|}{2016} & \multicolumn{2}{|c|}{2015} \\
\hline & Amount & $\begin{array}{l}\text { Year-on-year } \\
\text { Change (\%) }\end{array}$ & Structure (\%) & Amount & $\begin{array}{c}\text { Year-on-year } \\
\text { Change (\%) }\end{array}$ & Structure (\%) & Amount & Structure (\%) \\
\hline Total & 253,194 & 17.8 & 100.0 & 214,889 & -1.3 & 100.0 & 217,663 & 100.0 \\
\hline Gaming & 209,901 & 18.3 & 82.9 & 177,397 & -2.5 & 82.6 & 181,891 & 83.6 \\
\hline Shopping & 16,083 & 22.2 & 6.4 & 13,162 & 10.0 & 6.1 & 11,969 & 5.5 \\
\hline Food \& Beverage & 12,789 & 16.4 & 5.1 & 10,985 & 4.0 & 5.1 & 10,564 & 4.9 \\
\hline Accommodation & 6966 & 11.3 & 2.8 & 6260 & -1.8 & 2.9 & 6375 & 2.9 \\
\hline Passenger Transport & 5766 & 4.4 & 2.3 & 5521 & 2.1 & 2.6 & 5405 & 2.5 \\
\hline Travel Agency & 1688 & 7.9 & 0.7 & 1565 & 7.2 & 0.7 & 1459 & 0.7 \\
\hline
\end{tabular}

Source: Macau Statistics and Census Service, 2018. 
Table 2. Macau restaurant industry historical data.

\begin{tabular}{cccccc}
\hline & 2012 & 2013 & 2014 & 2015 & 2016 \\
\hline Establishments (No.) & 1678 & 1918 & 2112 & 2284 & 2265 \\
Persons Engaged (No.) & 21,987 & 26,079 & 30,360 & 32,313 & 32,551 \\
Receipts (Million MOP) & 6899 & 8403 & 9602 & 10,039 & 10,633 \\
Expenditure & 6309 & 7758 & 9111 & 9944 & 10,484 \\
Gross Value Added & 2716 & 3220 & 3612 & 3568 & 3928 \\
Gross Fixed Capital Formation & 196 & 348 & 393 & 604 & 346 \\
Gross Surplus & 591 & 665 & 507 & 131 & 174 \\
Gross Surplus Ratio (\%) & 8.6 & 7.9 & 5.3 & 1.3 & 1.6 \\
Gross Surplus-Expenditure Ratio (\%) & 9.4 & 8.6 & 5.6 & 1.3 & 1.7 \\
\hline
\end{tabular}

Source: Macau Statistics and Census Service, 2018.

get involved in this industry. The receipts also increased year by year (Macao Statistic and Census Services, 2018).

Therefore, food and beverage sector is a vital market segment for Macau's tourism industry. Macau government expected to change Macau's tourism destination image to leisure destination instead of gamblers' destination, over-relying revenues on gambling. In this situation, this study creates value.

Aforementioned service environment can create customers' satisfaction. If service provider can make use of physical environment, it can enhance customer approach or avoidance decision and facilitate customer social interaction (Parish et al., 2008). Many studies highlighted the result of service environment which lead to buying decision and behavior. Particularly focus in employees and customers. This study addresses this void by re-examine Bitner's (1992) servicescape model and identify other basic elements which may not be included in the previous study. Apart from the ambient conditions, space or function, signs, symbols and artifacts, they might have a need beyond the previous mentioned from these traditional environmental dimensions.

The plan for this study is develop an update and re-examination of the model (Bitner, 1992) and identify the basic need for the Chinese visitors. The research focuses on better understanding and expands the original framework in external service setting, or "perceived servicescape" (Zeithaml et al., 2009). Our target interviewees based on Chinese visitors which had encounter the service experience in local Macau full service restaurant includes eastern and western restaurants, fast food chain restaurant was not be included in our study.

\subsection{Study Rationale}

Many scholars highlighted the importance of the service environment (Ryu \& Han, 2010; Chua, Othman Boo, Abkarim, \& Ramachandran, 2010; Wang \& Mattila, 2015), however, limited discussion found in the catering service in Macau. Furthermore, combined impacts of food expectation and patronage inten- 
tion from Chinese visitors' perspective were very little. This conceptual framework had been developed over the last two decade, it crucial for further investigate what kind of special features in the service environment may affective influences customers' expectations, it urgent need to re-examine their service environment and align with their perceived image and response.

Consequently, this study aims to bridge these gaps by using a conceptual model, sevicescape that explicitly accounts for the effects of two components (food expectation and patronage intention) from Chinese visitors' perspectives in Macau's restaurant segments. The study aims to investigate customer perception of service environment of restaurants; the influences of service environment on the customers' food expectation in the catering industry; the influence of service environment on the customers' patronage intention of Macau catering industry and provide recommendation to the practitioners to improve the service environment.

Because physical environment (servicescape) is believed to be one of the most influential factors affecting a customer's psychological state and behaviors in hospitality service situations, there is a need to understand how customers' emotional states and behavior change based on their perception of environmental elements (Ryu \& Jang, 2007).

Practically, this study can provide restaurants' managers with various insights into the important role of physical environmental elements on customer satisfaction and customer loyalty, promoting patronage intentions and increasing restaurant revenues and market share. This study offers tools to guide service environment design and provides useful information for restaurant managers to update the service environment.

Thus, this study is the first to attempt by assessing the influence of service environment on Chinese visitor's food expectation and patronage intention, which could create an impact on their satisfaction in the hospitality industry, particularly in the restaurant context.

\section{Literature Review}

\subsection{Service Environment}

Service environment, also called servicescape, relate to the style and appearance of physical surroundings and other experiential elements encountered by customers at service delivery site (Bitner, 1992). It takes so much time and effort to design the service environment, which is considered as an art. Service environment can't change easily when it was designed and built.

Service environment can shape customers' experiences and behaviors. For organization that offers high-contact services, the design of service environments plays an essential role in creating corporate identity and shaping customers' experiences. The purposes of service environments are:

1) Helps corporation to create a unique image and positioning.

2) Relate to the exterior and style of physical surroundings and other expe- 
rience factors.

3) Service environment can affect customers' behavior in three ways:

Includes to convey the unique nature and quality of the service experiences through symbolic cues; make service environment stand out from other competitors and attract target customer or market segmenting; use colors, scents, sounds and spatial design to improve service environment and heighten the required service experience.

Service environment can reinforce image, positioning and differentiation. Because of the intangible feature of service, customers use the service environment as an indicator to observe the service quality, so the corporation should make great efforts to design the customer required image. For example, when customer see the reception areas of some high-end hotels, it's always presented with elegant design, which may affect customer perceived quality of purchasing because the spatial design of hotel and the good is surrounding by a prestige image. This kind of hotels communicate to the customers about the quality of service experiences, giving enough service expectation and reinforcing hotel image.

Service environments are functional. Some companies express their images by locating in inexpensive neighborhoods, reducing waste of space and dressing employees in low price uniforms. This kind of design can be useful for business people when a restaurant set aside a table with laptops for them to use as an office place. The purpose of this service environment is to convey a distinctive or new concept of previous customer desired service.

Service environment as part of value proposition, shapes the feelings and reactions in customers and employees. Many theme parks use service environment to improve service offerings. For instance, Disney views its show as a live performance and the physical setting as a movie set. Everything must be carefully designed and constructed to bring home the feeling of theme and service to the guest (Johnson, 1991), which lets guests feel happy and increase their repeat visitation. Service environment can facilitate the service encounter and enhance productivity. For front-line staff, they consciously check their outfits and look through mirrors before meeting and serving customers. In fast-food restaurants, the area for tray-return and the on-wall notices remind customers to return their trays to a great extent.

Services are largely intangible in hospitality so that when customers tend to depend on physical cues to help them evaluate the product before they buy it. Marketers developed the term "physical evidence" to replace physical cues. Physical evidence includes different aspects of organization's facility as well as other forms of tangible communication. Physical affects customers include exterior (such as exterior design, signage and parking), interior (such as equipment, layout and sound) and other tangibles (such as employee dress, brochures and web pages). Physical evidence impacts on perceptions of service quality and satisfaction, as well as the intention to re-patronise and the willingness to recommend (Hutton \& Richardson, 1995). Besides, evidence affects word-of-mouth, as 
customers more readily recommend a physically pleasing environment to friends (Hutton \& Richardson, 1995). Zeithaml et al. (2009) suggests that physical evidence can be used to distinguish services from those of the competitor, and therefore changes in the physical environment can be used to positively reposition a service, resulting in the attraction of a new market segment. Physical evidence can thus be used to achieve marketing goals (Aubert-Gamet, 1997).

\subsection{Physical Evidence Affects the Customer Expectation}

Physical evidence has a profound effect on customer experience no matter it's mundane (bus or subway ride), meaningful (special birthday) or spectacular (several weeks' vacation) experience, which affects customer satisfaction, emotional connections through company delivery experience and social and personal interaction through other experiences.

Marketers have recognized the impact of physical space and intangibles in creating customer experiences. Berry, Wall, and Carbone (2006) illustrated that when customers assess services, they mainly base on performances rather than objects and rely on the numerous clues that are embedded in performance when choosing services and evaluating service experiences. There are two categories of cues that make up the customer experience. The first is based on the actual function of the commodity or service. The second category focuses on the emotions and includes the smells, sounds, sights, tastes and textures of the good or service, as well as the environment in which it is offered (Berry, Carbone, \& Haeckel, 2002).

\subsection{Customers' Responses, Positive and Negative Impacts on the Service Environment}

\section{Stimulus Organism Response Model-Customers Responses}

At the most basic level, a pleasant environment attracts customers; however, an unpleasant environment avoids customers buying behavior. Arousal acts as a significant element of the basic level of pleasant behavior performance. If the environment is pleasant, increasing arousal will lead to a positive response. On the contrary, if the environment is unpleasant, manager should avoid increasing arousal levels, making customers feel more relax rather than stressful.

Developed by Mehrabian and Russell (1974), SOR model is the main method to study consumer behavior/response in store environment. This model was originally designed for environmental psychology, but later several studies have proved that it is suitable for retail industry and service sectors. SOR model shows that the shopping environment contains stimuli (S) that affect organisms (O) and result in approach or avoidance response $(\mathrm{R})$ behaviors toward the store and in behaviors like store searching, intention to purchase, and repurchase intention. This framework examines the environmental cues (e.g., color, lighting, music, crowding, fragrance, and layout) and their related influences on customers' internal states and external responses in retail store environments (Mehrabian \& Russell, 1974). 
For retailers, the most important aspect of the model is that it helps to understand how different stimuli affect consumer responses. Most retailers want to increase customers' approach response behavior. Approach behaviors refer to all positive actions that might be directed toward a particular setting, for example, intentions to stay, explore, and affiliate, while avoidance concerns the opposite (Mehrabian \& Russell, 1974; Bitner, 1992). Therefore, it's crucial to investigate which factors of physical environment could elicit the senses of pleasure among target customers because these senses largely let them spend more time and money.

Pleasure is a direct, subjective response to environment, depending on what levels of individual like or dislike the environment. Arousal refers to stimulate the individual feels, ranging from deep sleep (lowest level of internal activity) to highest levels of adrenaline in bloodstream. For example, when bungee jumping, the arousal quality is much less subjective than its pleasure quality (Lovelock \& Wirtz, 2007).

Russell separated cognitive parts of emotions from these two emotional dimensions. So the emotion of anger about service failure could be regarded as high arousal and high displeasure. If a customer attribute a service failure, but a company does not avoid and let it happen again. This will lead to high arousal and displeasure.

The advantages of the model (Mehrabian \& Russell, 1974) identify direct assessment of customer feelings in service environment. So the restaurant managers should set some targets for affective states. For example, a high-arousal environment combine with pleasure can reach customers' satisfaction.

In environmental psychology, the typical outcome variable is "approach" or "avoidance" (Lovelock \& Wirtz, 2007). While these two types of behaviors in servicescape, it brings both positive impacts and negative impacts. A positive perception of servicescape should create approach behaviour. This approach response includes a motivation to move toward the place, the environment, and consequently through the servicescape (Sullivan, 2002). A positive environment in which twenty-nine customers are feeling good and exited has the possibility to increase their potential purchase behaviour. Moreover, we saw that servicescape's elements, such as music or odour, possibly will change the time perception of customers (Sullivan, 2002).

When customers have a bad viewpoint of servicescape, they may adopt avoidance behaviour. They might move away from the place and decrease their participation, thereby reducing their potential buying behavior. This negative experience may through Word of Mouth (WOM) to share bad impacts to other consumers. Hence, it should be a priority for companies to create, manage and improve servicescape (Hightower, 2003).

The term "service recovery" refers to the actions taken to: 1 ) rectify the service failure; and 2) with a view to customer retention, convert the negative attitudes of dissatisfied customers to positive attitudes (Miller, Craighead, \& Karwan, 2000). 
The development of an effective recovery strategy is essential to retain customers, preventing negative word-of-mouth communication, and generating trust and loyalty (Chua, Othman, Boo, Abkarim, \& Ramachandran, 2010). In the case of a bad servicescape, customers tend to change their behaviour and give a bad response to servicescape especially if the firm does not adopt recovery (Keaveney, 1995). For company, it's important to listen and understand the responses of the consumers in order to provide the best service environment and receive positive responses which may enhance brand image and differentiate in service marketing.

\subsection{Gestalt Psychology}

The term "Gestalt" is derived from German, and signifies form, shape, or a whole configuration (Schiffman, 2001). Gestalt psychology was proposed by Max Wertheimer, Wolfgang Köhler, and Kurt Koffka at the beginning of the 20th century. The concept of Gestalt bases itself on assumptions about how living organisms relate to their environment (Carmer \& Rouzer, 1974). The basic Gestalt theme is that the whole is different from the sum of its parts (Schiffman, 2001). However, most prior studies have focused on a single environmental cue (Lin, 2004; Wirtz et al., 2000). Applying the concept of Gestalt, Lin and Mattila (2010) suggested that people generally receive a variety of stimuli from a restaurant servicescape. Because customers take into account the various aspects of satisfaction are not only based on single stimuli. They evaluate the overall dining experiences through the whole configuration. However, based on their needs, they organize them cognitively into groups and derive holistic images from the stimuli (Schiffman \& Kanuk, 1978). Gestalt psychologists suggest that people perceive physical environment through figure and ground principles which stand out from its surrounding and background.

\subsection{Strategic Roles of Service Environment}

Service encounters encompass interactions among customers, service employees, servicescapes, and all aspects of service provision (Lockwood, 1994). Due to the complexity and many design elements of service environment, Bitner (1992) classified three main dimensions: "ambient conditions", "spatial layout and functionality" and "signs, symbols and artifacts." Because the individual tends to perceive holistic environment about these dimensions, it's important to fit each dimension together.

This model classifies into two moderators, employee response moderators and customer response moderators. However, the same service environment can have different influences on different customers, because this is very subjective. This model also includes employee responses. Considerably, employees spend more time than customers especially the front-line employees so designers should aware of environment enhances and productivity of service delivery. There are employee responses and customer responses in internal responses. 
Both of them include cognitive, emotional and psychological responses. Internal responses can lead to approach and avoid behavior. Major the model indicates the following environmental stimulation for both employees and customers:

1) "Ambient conditions" include five senses of those characteristic of environment such as temperature, lighting, noise, music, and scent. Five senses mean that ambient conditions will unconsciously affect people's emotional well-being, perceptions, attitudes and behaviors. Music, scent and color are three major tools of ambient conditions in service settings.

a) Music

In servicescape, music can have a powerful effect on customer although it's merely audible music. Numerous research studies have found that fast-tempo music and high-volume music increase arousal levels (Holbrook \& Anand, 1990; Rohner \& Miller, 1980) which can increase the pace of customer behaviors. People may adjust their behaviors to match the tempo of music voluntarily or involuntarily. Music can as a tool to shape customer behavior in service settings. Several field studies reported that shopping and dining pace, and in some instances expenditures, are influenced by the volume (Smith \& Curnow, 1966) and tempo (Milliman, 1982, 1986) of background music. Slower tempos and lower volumes tend to make retail patrons shop or eat at a more leisurely pace and in certain instances spend more money than faster tempos and higher volumes (Duncan, 1996). So music may voluntarily or involuntarily affect guest's perception.

b) Scent

Customers may be or may not be aware of the ambient smell because it's not related to any particular product. In aromatherapy, it's generally accepted that scents have distinct characteristics and can be used to solicit certain emotional, physiological, and behavioral responses (Lovelock \& Wirtz, 2007). The fragrance of lavender can make people relaxed and calm, and help to create a sense of comfort. For example, when people try on Nike sneakers in floral rooms, they are more willing to buy. At Walt Disney World in Orlando, the smell of chocolate chip cookies baking is piped from the underground to the park's main street inside the front gate to greet guests, create warm feelings, and whet their appetite for a treat (Wall \& Berry, 2007).

c) Color

Color pervades every aspect of our lives, embellishes the ordinary, and gives beauty and drama to everyday objects. Researchers have found that colors have a strong effect on people's feeling (Gorn, Chattopadhyay, Yi, \& Dahl, 1997; Crowley, 1993). Research in the service environment shows that although people have different preferences for color, they tend to use warm colors (e.g., the warmest color, orange). Warm color is related to elated mood states and arousal, while cold color can reduce the arousal level and lead to peaceful, calm, love and happy mood. However, the warmer (defined in terms of hue, brightness, and saturation) the color in a service environment; the more negative the affect and the longer the perception of waiting time duration (Baker \& Cameron, 1996). 
2) "Spatial layout" is composed of counters, machinery, equipment, and furnishings and how they are arranged. "Functionality" refers to the ability of the same items to facilitate performance of service transactions. In restaurants, for instance, layout refers to the ways in which seats, aisles, hallways and walkways, food service lines, restrooms, and entrances and exits are designed and arranged (Kim \& Moon, 2009). For example, seating comfort has been found to influence pleasure in football and baseball stadium facilities (Wakefield, Blodgett, \& Sloan, 1996). Stress caused by poor seating has been found in workplace settings (Nevin, 1991). Spatial layout has a direct effect on customer quality perceptions, excitement levels, and indirectly effect on desire to return, which makes people feel constricted. This implies that service or retail facilities that are specifically designed to add some level of excitement or arousal to the service experience, such as those in an upscale restaurant, should provide space to facilitate exploration and stimulation within the physical environment (Wakefield \& Blodgett, 1994). The locations of tables in restaurants have a tremendous impact on the overall experience of a customer. Table placement has the ability to transmit a sense of privacy, portray the functionality desired, and operate as a boundary for the customer (Lin, 2004). Ryu and Jang (2008) revealed that layout was a significant determinant of the level of pleasure in an upscale restaurant context.

3) "Signs, symbols, and artifacts" displayed as exterior and interior elements of a structure to communicate the firm's image, which will help and guide customers. They can be used as labels (e.g., name of department), for giving directional (e.g., entrances, exits and toilets), and behavior rules (e.g., turn mobile devices to silent mode). For example, there are some reinforce rules in Macau, smoking is prohibited within 10 meters of Macau Bus Station. Because customer will be disoriented when they cannot derive the clear signals from servicescape so that will lead to anxious and uncertain toward how to obtain service. The challenge for servicescape designers is to use signs, symbols, and artifacts to guide customers the process of service delivery in a clear way and teach them service process as intuitive as possible, which let customers not feel angry and frustrated in service environment.

What's more, people are part of service environment. The appearance and behavior of both service personnel and customers can reinforce or detract from the impression created by service environment (Lovelock \& Wirtz, 2007). For service firms, it's necessary to recruit staff with specific roles and costume them in uniforms that they can coordinate with servicescape. Customers may consider neat and clean outfits of restaurant as good service quality, making a good first impression and inspiring more confident and meanwhile, it boosts employee productivity. Because the good quality interaction between customers and employees leads to desirable outcomes such as loyalty, repeat patronage, and profit (Heskett et al., 1994).

Sevicescape have to be holistically and provide customer a comprehensive view. In order to produce an overall impression of a beach environment for customers, the Disney company hosted an indoor "beach party" for the press at one 
of its hotels for the setting included sand, the smell of suntan oil, a boardwalk arcade, music, lighting, the sound of surf, and other clues (Carbone \& Haeckel, 1994). For example, restaurant manager may consider regulating the arousal element of scent and music so that can elicit the desires of customer responses. In esthetic values, service environment has already built up, but designers neglect customer's perspectives of design. How to design service environment in an appropriate way are as follow:

1) Keen observation of customer' behavior and response to the service environment.

2) Receive feedback and ideas from front-line staff and customers, using a broad array of research tools ranging from suggestion boxes to focus groups and surveys.

3) Field experiments, which can be used to manipulate specific dimensions in an environment so that the effects can be observed (Lovelock \& Wirtz, 2007).

However, Bitner (1992) did not considered the social aspect of physical environments. In an effort to extend Bitner's (1992) study into leisure settings, Wakefield \& Blodgett (1996) examined the effects of layout accessibility, facility aesthetics, electronic equipment, seating comfort, and cleanliness on the perceived quality of the servicescape.

Servicescape can play in different strategic roles, such as package, facilitator, socializer and differentiator (Lovelock \& Wright, 2007; Bitner, 1992).

1) Package

Servicescape or physical evidence wrap the service and convey to customer through the appearance rather than inside. This package role is considered as initial impression and customer may increase their expectations. Particularly in some new firms for attracting new customer and bring an amazing image. Embodied in dress appearance, the package role conveys the image through the uniforms in corporation.

2) Facilitator

Facilitator role means aiding the performances of person in service environment. A well-designed facility can lead to pleasure from customers' perceptions and employees' performances. On the contrary, poor and inefficient design let customers and employees feel terrible. For example, if an international airport with scarce signs, no enough place for customers to stay and have rest, customers may feel frustrated and employees largely have no motivation working there.

3) Socializer

The servicescape also helps to convey expected roles, behaviors and relationships between employees and customers. For example, in Starbucks locations, the company designed a traditional environment for customer spending social time rather than pick up a coffee then leave, and this design let customers spending more time to interact.

4) Differentiator

Physical evidence affects the positioning of a service, the servicescape is frequently one of the most important elements used in positioning a service orga- 
nisation, thereby acting as a differentiator (Lovelock \& Wright, 2007; Bitner, 1992). For example, there are visual design in shopping malls, different colors display different products, and this strategic role reinforce their positioning in the sight of customers and employees.

\subsubsection{Evaluation in Servicescape}

Often in hospitality services, numerous features are either ambiguous or credence attributes, thus specifying what consumers perceive and subsequently evaluate is difficult (Wirtz \& Bateson, 1995). If consumers do not evaluate the full scope of a service or an experience, they may use limited information to establish their perceptions, which in turn shape their expectations (Hoch \& Deighton, 1989). Research indicates that the perception of individual attributes may be influenced by overall impressions, just as strong impressions regarding one attribute may influence the perception of all other attributes (Wirtz \& Bateson, 1995). This is known as the "halo effect". If just using one attribute at a time to evaluate individual settings and to limit the halo effect, it could cause bias and cannot reflect customer overall evaluation. Harris and Ezeh (2008) identified nine features in servicescape model on customers' loyalty intentions in a restaurant, which demonstrated that customers used multiple elements to observe the servicescape and nine features worked in tandem. So the evaluation in servicescape can be multidimensional.

\subsubsection{Behavior in Servicescape}

The environmental psychology has emphasized the relationship between human and physical environment. The current focus on the customer experience has also drawn attention to the effects of physical spaces and design on customer behavior (Berry, Wall, \& Carbone, 2006). Recent studies explored the effect of servicescape fast-food by short and long-term effects, which found out that remodeling increase customer perception, spending and positive image.

A considerable body of research has confirmed that perceptions of servicescape lead to cognitive, emotional, and physiological responses that influence customer behaviors (Bitner, 1992; Wakefield \& Blodgett, 1996). For individual behaviors, environmental psychologists elaborate on two forms of behaviors, approach and avoidance. In customer responses, approach such as attraction, stay/explore and spend money (Lovelock \& Wirtz, 2007).

Additionally, the servicescape influences the social interactions between and among customers and employees, emerged in interpersonal services. Environmental variables such as proximity and seating arrangement occur between customer and employees, customer and other customers.

\subsection{Food Expectation and Food Quality of Customers}

In the service management literature, there are various definitions of customer expectations. Expectations can be described as variable standards which are formed based on factors such as needs, objectives, past personal or indirect ex- 
periences with an organisation, as well as the substitutes available (Pizam, 1999). Expectations are defined as beliefs about service process and form the standards against which actual performance will be assessed (Zeithaml \& Bitner, 2003). Mohsin et al. (2007) revealed that value for money, variety and quality of the products available, staff-related skills, staff presentation and manners, and well-timed service were ranked as the five most important expectations of customers in New Zealand restaurants and cafes.

Kim (2009) noted that managing customer expectation facilitates customer satisfaction, so expectations serve as a major determinant of a customer's service assessments and satisfaction; thus firms that focus on customer expectations have a more satisfied customer base which influence repurchase intentions and leads to profit (Han \& Back, 2007).

When a customer compares her/his expectation with the sum of her/his weighted experience, she/he is regarded as satisfied. However, dissatisfaction occurs when expectation comparison does not give a feeling of fulfilment or pleasure (Ryu \& Han, 2011). There are five levels (types) of customer's expectations, ranging from minimum tolerable expectations, through acceptable expectations, experience-based norms, normative "should" expectations to ideal expectations or desires (Marković et al., 2010).

Food quality is one of the most critical components of a dining experience (Namkung \& Jang, 2007; Sulek \& Hensley, 2004). Clark and Wood (1998) identified food quality and food variety during the dining experience as the most influential factors of customer loyalty. MacLaurin and MacLaurin (2000) explored nine factors of theme restaurants in Singapore and included food quality as one of the important elements in addition to theme concept, service quality, menu, atmosphere, convenience, value, product merchandise, and pricing. Mattila (2001) indicated that the top three reasons for customers to patronize their target restaurants in the casual dining sector were food quality, service, and atmosphere. Food and service can be considered the most critical components for customers to determine satisfaction and future behaviors toward a restaurant (Ha \& Jang, 2012).

The quality measuring scales such as SERVQUAL, TANGSERV, and DINESERV, to a great extent have been used to explain the relative importance of functional quality (i.e. what services are provided) in shaping customers' future responses (Mathur \& Gupta, 2019). Beside service quality, some studies have suggested the importance of technical quality aspects-such as food, to evaluate customer's response (Clark \& Wood, 1998).

Even though the food itself being a fundamental component of restaurant experience, yet quality-focused studies have often overlooked its importance in effectuating customer's choice, emotion, and purchase behaviour (Mathur \& Gupta, 2019). To better understand the role of food expectation, it is extremely important to include the Servicescape model to determine customer's restaurant experience. Thus, this study highlights food expectation in customer's perspective. 


\subsection{Patronage (Visit) Intentions of Restaurant and Destination}

Baker and Crompton (2000) defined revisit intentions as the intentions of visitors to revisit within a year and their willingness to travel to the destination often. Although the re-patronage intention is subjective by individual, an important factor of customer return destination is satisfaction, which defined as the "perceived discrepancy between prior expectation and perceived performance after consumption" (Pivac et al., 2011) and it is also a central variable in consumer behavior research because of its strong influence on customer loyalty and intention to revisit a location (Kim, Duncan, \& Chung, 2015). Revisit intention has been regarded as an extension of satisfaction rather than an initiator of revisit decision making process (Um, Chon, \& Ro, 2006). Tourists' satisfaction with the destination positively affects their intention to revisit. Thus, it's essential to satisfy customer in order to increase re-patronage intention and next purchasing.

\section{Methodologies}

This study adopted a descriptive qualitative design. For sample size in data collection, (Thomson, 2010) argued that the average sample size was 25, but it is recommended to plan for 30 interviews to fully develop patterns, concepts, categories, properties, and dimensions of the given phenomena. Creswell (2013) provided observations and some recommendations of sample size ranges for grounded theory methodology and 20 to 30 participants considered to be adequate, which can also develop a well-saturated theory. So this study interviewed thirty respondents who were Chinese tourists and had visited restaurants in Macau. Their comments from the interview were up to theoretical saturation (Crouch \& McKenzie, 2006). The descriptive research designs collect evidence that helps the researchers understand the impact of service environment that had effects on Chinese visitors' food expectations and intentions to patronage.

This study used a descriptive case study method, involving in-depth study of individuals. This study applied a descriptive approach to Chinese visitors' viewpoint of food expectations and patronage intentions toward to the service environment in Macau catering industry. The main research questions were measured as follows: firstly, the interviewees were asked what is their perceived value in physical environment sector; secondly, they were asked to describe their food expectations in physical environment sector; thirdly, they were asked whether the service environment will affect their patronage intention or not; at last, they were asked to provide recommendations for catering marketers to enhance service environment.

Samplings adopted purposive sampling to gather data. Compared to the logic and power of random sampling derives from statistical probability theory, the logic and power of purposeful sampling lies in selecting information rich cases for study in depth (Patton, 2005).

For data analysis we adopted content analysis method to analyze qualitative 
data, responses from interviewees such as radio recording and field notes can provide reliable information. The record data was transcribed into traditional Chinese, then translated into English. The information of interviewees was written in a form. In order to conduct a focused analysis of specific data, coding is necessary. For opening coding, the researcher reads each transcript and makes notes in the margins of words, theories or short phrases that sum up what is being said in the text.

\section{Result and Discussion}

In total of thirty participants were interviewed in this study. The interview took 45 minutes to one hour of each participant. The in-depth interviews were conducted at the Border Gate, Macau International Airport and Taipa Ferry Terminal. The age of the interviewees ranged from 19 to 60 years old and were distributed as follows: $33.3 \%$ ( 10 out of 30 ) were 18 to 23 years old, $50 \%$ ( 15 out of 30 ) were 24 to 38 years old, $6.7 \%$ ( 2 out of 30 ) were 39 to 52 years old, and $10 \%$ (3 out of 30) were 53 above. Approximately $43 \%$ of the respondents (13 out of 30 ) were male and $57 \%$ (17 out of 30 ) were female. For the income level, $43 \%$ (13 out of 30) of the respondents were below $4000 \mathrm{RMB}, 33 \%$ (10 out of 30 ) were 4000 to 8000 RMB and 23\% (7 out of 30) were above 8000 RMB. For visitor types, half of them are overnight visitors.

Findings are presented the viewpoints from the 30 respondents for each question. The characteristics presented were related to four research questions. For customer perception of service environment, they valued hygiene factors, style of decor, space, lighting, layout, hearing condition, color, available equipment, staff accessory presentation, food presentation, signboard, background music and humanity facilities.

Customers expected food in different ways such as the taste of authenticity, maintain the food standard, characteristic, affordable price, publicity, scent, taste, diversification, fusion, portion, freshness, be easily found and present to satisfy visual feelings. Service environment plays an important role in the food expectation of customer.

They also thought service environment should provide slow tempo of music, quiet environment, humanity facilities, suitable temperature, enough lighting and so on that greatly capture the patronage intention of customers.

The respondents figured out many recommendations for industry practitioners to improve the service environment.

\subsection{Chinese Visitors' Perceptions of Service Environment of Restaurants}

Table 3 shows Chinese visitors' perceptions of service environment in the restaurants of Macau, most of them concerned about the style of decor (20), space (14), hygiene condition (11), equipment (8), layout (3), sound (2) food presentation (2), color (1) and staff accessory presentation (1). As a visual sense, style of 
Table 3. Chinese visitors' perceptions of service environment in the restaurants.

\begin{tabular}{cc}
\hline Service environment element & Number of participant \\
\hline style of decor & 20 \\
space & 14 \\
hygiene condition & 11 \\
equipment & 8 \\
layout & 3 \\
Sound & 2 \\
food presentation & 2 \\
color & 1 \\
Staff accessory presentation & 1 \\
\hline
\end{tabular}

decor was the first thing that most of Chinese visitors would affect when they entered the restaurant. In terms of the space, some of interviewees thought the space is limited and small in Macau's restaurant. Customers evaluate the hygiene condition of food by the hygiene level of foodservice establishment because it relates to food safety issue and will affect their patronage to restaurants. The basic equipment that interviewees required include tableware, drinking water, toilet and air conditioner. Layout was thought to be appropriate and tidy while not be so compact. From the perspectives of two respondents, it was noisy during the procedure of having a meal in the restaurants of Macau. Food presentation is not only an image of food itself but also an impression of restaurant. If the food presents in a beautiful and delicate way, it will draw attention from customers. For staff accessory presentation, one interviewee worried if staffs can wear uniforms in the process of providing services.

From the perspectives of most interviewees, service environment was quite an important thing. Hygiene condition and style of decor were two keys that they cared about. Hygiene condition should meet the basic standard. When customers enter a restaurant, they feel there is no oil stains on the floor and tableware. The table can be cleaned up quickly after the leaving of previous customers. Only four interviewees disagreed with this because they considered that the food is more important. They specially cared about the quality of food.

Basically, Chinese visitors were concerned about the style of decor and hygiene before they made a decision to this restaurant. Besides, one interviewee mentioned the humanity of design or humanity equipment. For example, the separation of toilet for men and women can influence her visit to a restaurant.

\subsection{The Influence of Service Environment on the Chinese Visitors' Food Expectation of Macau Catering Industry}

Interviewees concerned about different types of food expectations. They valued the food choice and diversification from the menu (11), the characteristics of food (8), the taste of authenticity (4), food fusion (3), portion and food freshness 
(1). Due to the special geographical location and historical background of Macau, most of Chinese visitors pursued different types of cuisine. Food characteristics are in close connection with the unique flavor or signature dish of restaurant. Food fusion can be considered as a combination of two different types of food, such as combination of Chinese cuisine and exotic cuisine. With the continuous improvement and development of gastronomy, customers consider both the taste of authenticity and the characteristics of food and food fusion. Instead of using frozen food, food portion should be bigger and keep the freshness.

Most of interviewees deemed that service environment can affect their food expectations. Under the circumstances, they valued hygiene factors (10), style of decor (9), facilities and accessory (7), food presentation (2), space (1) and electronic payment method (1). The hygiene condition needs to reach a basic level at least. Because of different needs of the style of decor, customers should be made feel comfortable.

For facilities and accessory, most of interviewees required bright lights and air conditioners. As an impression of food, food presentation can offer customers a visual sense and affect their expectations of food. If food presents a bad image, it will reduce expectations of customers. There should be a moderate dining space which can provide a comfortable atmosphere for customers. If the space is too narrow, it may lead to discomfort. Electronic payment is a trend that can settle their payment. Although some interviewees stated that service environment can't affect their food expectation, the staff service and food price are more consider and lead to their buying decision.

\subsection{The Influence of Service Environment on the Chinese Visitors' Patronage Behaviors and Preferences of Macau Catering Industry}

According to the impression of service environment on interviewees, they can decide whether to patronize the restaurant. Most interviewees (22 out of 30) patronized Macau restaurants on the basis of service environment. This is closely connected with style of decor (9) and hygiene condition (6), which can let customers have positive or negative impressions on restaurants. If they have positive impressions, they will patronize it largely. If they generate negative impressions, they will feel that the food quality is poor and they are not willing to patronize. Several interviewees considered the condition in sound and space, because they prefer to dine in quiet and spacious places.

For the purpose of stimulating the patronage intention of customers, there are some features that Macau restaurants should provide:

1) Facilities and accessory should satisfy the basic needs of customers, including tea, lighting, air conditioner, comfortable seat and washroom. These can leave a good impression on customers and they may revisit the restaurant next time.

2) With regard to style of decor, customers pursue appropriate or comfortable decoration. A comfortable environment can let customers feel at ease and enjoy 
more time or eat more food in restaurants.

3) An area for luggage placing. Customers may bring a lot of luggage when they have a travel. If the restaurants can offer a luggage area, they will attract more customers to visit them. Or if they prepare some small luggage boxes for customers to place personal clothes and bags, they will win a praise from customers.

4) Electronic payment as a new payment method, is popular among Mainland Chinese users. It's convenient for customers to not exchange money for completing their payment.

5) Area or cables for the charging of mobile phone. When customers see the low battery on their phone, they will need to charge it. If restaurant can provide a place of charging, they feel satisfied with the service environment.

6) QR code ordering as a new electronic equipment can assist customer to see the menu clearly. It will not waste the resource of restaurant staffs and the time of customers to call the staffs.

7) Offer games when customers line up. When customers wait in line, they may feel boring or even want to leave immediately. If small games can be offered, they will become willing to have a waiting.

\subsection{Recommendations for Industry Practitioners to Improve Service Environment}

Because Chinese visitors thought highly importance of the style of decor (11), they preferred bright or warm lighting (8), spacious restaurants (8), quiet environment (7), good hygiene condition (7), not strong scent (2) and colorful service environment (2). Therefore, catering industry practitioners should decorate the restaurant according to the requirement of the public and create a comfortable atmosphere with bright or warm lights. Practitioners should slightly expand the space, maintain food hygiene and keep food safe and clean. Having good kitchen hygiene is necessary.

For good hygiene, restaurant often have to keep clean and provide a safe environment to their customers. For color in decoration, people prefer warm color and it will draw people attention and their patronage choices.

For humanity facilities, the restaurants can be equipped with hand sanitizers, sprays or mouthwashes etc. Disposable hand sanitizers can be placed at cashier, so when customers come in restaurant.

For food presentation, it's better to show matching color of food on plates. The food presentation should balance portion and taste as well. Good food presentation should also match enough portion which will satisfy customer's need.

For electronic equipment, besides QR code ordering and electronic payment, online reservation is also important for customer patronage to a restaurant. Practitioners can set up a WeChat mini app or a lifestyle app for customers to accept the reservations online, which will let customers know the progress of the restaurant reservation, and notice them by messages. This won't waste their 
times when lining up.

For the staff presentation, it's necessary for staff to wear masks, gloves and uniforms. Customers will have good impression on catering environment if staffs dress in uniform rather than casual clothes. Besides the service environment, interviewees thought the price of food (11), quality and food taste (11), online comments (eWOM) (10), spacious (8) and the quality of food (7) can affect their patronage to a restaurant.

The price of food should be match with the service environment. Therefore, restaurants are suggested to make use of pricing to segmenting their markets, either cost leadership and differentiation in their market. The location of restaurant is also an important factor of customer's choice of patronage.

To conclude some of the new elements in the environmental dimension such as included food presentation, electronic equipment and humanity facilities in the environmental variables. The new perceived servicescape model (see Figure 2) includes food presentation which as a visual cue can lead customers to expect the taste of food and also influence how much they like the taste of food. The package role is considered as initial impression and customer may increase their expectations. Restaurant provides unique food presentation, apart from they can delight their customers, its might potentially influence their service expectation. People also use visual information to judge the freshness of a food (Wada et al., 2010) and how refreshing they expect it to be (Clydesdale, Gover, Philipsen, \& Fugardi, 1992; Zellner \& Durlach, 2002, 2003).

Besides, customers also highlighted the humanity facilities which were crucial in facilitating their service. Some of the caring facilities such as storage room for suitcases or personal belonging can facilitate service to their customers. Disposable hand sanitizers or other amenities can provide in the restaurant. Electronic payment become overwhelming in the world, customer expect settle the payment by mobile apps. Make use of electronic payment will lead to service satisfaction.

\section{Marketing and Academic Implication}

The study moves the servicescape paradigm forward and supported the expanded

Service Environment

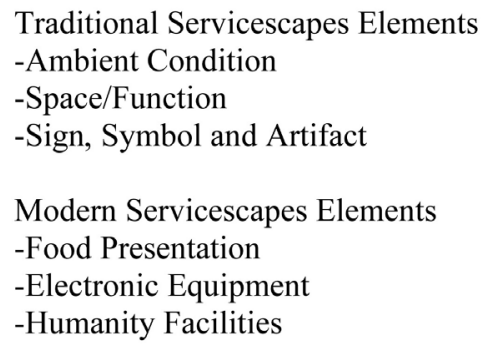

Customer Perception

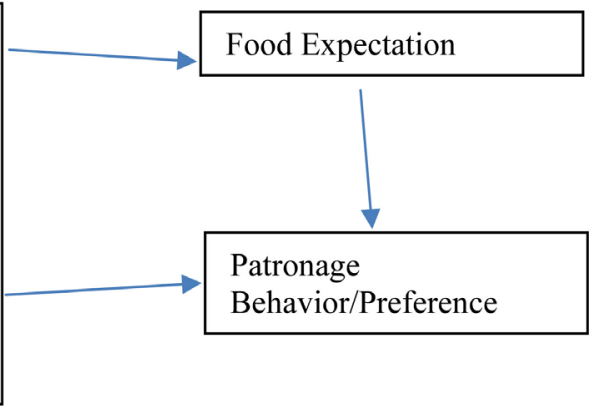

Figure 2. New perceived servicescape model. 
of environmental dimension. Previous scholar highlighted the foundation of the service environment which includes colors, scents, sounds and spatial design, however, besides those elements such as food presentation it vital for customer. They can provide a stimulate responses and acceptance. Therefore, in the ambient factors should include food presentation and make use of visual appeals and create quality satisfaction to the customers. Food presentation can create an impact on their hedonic consumption.

Marketers need to make use of facilitators such as electronic devices (i.e., bill payment or QR code) to increase consumer satisfaction when they settle their payment. Results also demonstrate customers' need not only limited to basic facilities. They need more humanity facilities for creating their satisfaction in service. Besides, in total of eleven interviewees mentioned about style of décor in the restaurant were important, the implication to the marketers they need to understand the Chinese "face culture" which they say "mianzi". This refers to a cultural understanding of respect, honor and social standing. For those who patronage the restaurant with unique style of decoration, it provides "mianzi" specially this action may cause them gain "mianzi" when they invited their friends to a nice restaurant. That provide evidence of the environmental elements in the framework by showing that among some customers their approach or avoidance behavior cause of consumption settings.

Bitner's (1992) framework which postulates the customers' consumption's setting and the results comprise new elements which provide industry practitioners more implication. Indeed, not all of the interviewees perceived that food presentation are important, but the outcomes had demonstrated customers did concerned the décor design and the food serving, pay attention to the details in the food presentation. It was quiet challenge for a restaurant manager, need to manipulate the layout of the restaurant and at the same time they need to ensure the food presentation and quality fulfill the need of their customers. Therefore, in term of servicescapes' design, managers need to understand their target customers particularity under the different geographic segments' they have to employing a vast array of servicescape stimuli.

From the academic perspectives, research should consider exploring different groups of target customers in the different way of response to the service environments. In this study what we had adopted Chinese as target interviewees, the customer response differently, therefore, researchers in the future need to examine how and why these groups of customers they have different response to the environmental setting.

By exploring the influences of the service environment, research can have a better understand of service expectation may come from various elements, humanistic requirement lies on the need to customer response. Therefore, research can expand the model and base on the customers behavior and examine the psychology or religion and culture aspect for further investigation. We encourage researcher future to explore the extent to different group of customers perceived similarity or differently among unknown customer in the service envi- 
ronment. That result can gain knowledge of the servicescape model and enrich the theory extension.

\section{Limitation}

The current study carried out a literature review on relevant studies, including secondary data analysis and in-depth interviews. Firstly, arrival visitors to Macau major over 70\% from Mainland China (Macau Statistic and Census Services 2019), in this situation, our target interview limited to Mainland Chinese visitors. Secondly, the sample size was relatively small, and consisted of only 30 interviewees which result are limited base on these samplings. Future studies should involve a larger sample size to receive holistic views. In addition, to improve the re-examination of the servicescape model, it should be conducted internationally to track changes in the service environment sector and to find out different and unique features provided for customers. Moreover, this research also ignored the moderating role of an employee as a part of service environment. Since this research mainly focused on environmental dimensions which primarily consisted of the interior and exterior physical environment of the servicescape model, it would be better to conduct further research on the social interactions between customers and employees. This is important since customers value employee engagement such as the behaviour of employees and their responses. Mixed method research techniques combining quantitative and qualitative analysis could also be used for extended analysis of customer loyalty and satisfaction.

\section{Conclusion}

This study adopted Servicescape model to further investigate the service environment on customers' food expectations and patronage intentions and find out service environment influences significantly on customers' food expectations and patronage intentions. Study highlighted three new dimensions including food presentation, electronic equipment and humanity facilities.

Our results highlighted the bill payment, reservation and QR code ordering in electronic equipment in the crucial physical evidence provide for the customers. These three kinds of new technology should be updated because nowadays people pay settle their bills not only based on credit card but also pay by their phones which will understand customers purchase patterns in a better way. What's more, the results also showed that customers valued eWOM like the comments in websites and applications and entertainment like snacks and live performances in service environment. Therefore, service providers should request and implement customers' feedbacks from online to offline. Arranging entertainment is to elicit the "fun" emotion of customers. However, limited research mentioned the food presentation and humanity facilities in service environment dimensions. It provides references for the industry practitiones who to satisfy customers' aesthetic appeal on food and activate humanized marketing. It 
will make a significant difference by taking consideration of customers' needs because visitors are the most significant contributors to tourism. Nevertheless, the effect Servicescape model on customers have long been recognized but lack of conceptual development, so academicians should explore more sufficient dimensions and compare related issue such as customers' emotions/experiences/ personalities, food quality or pricing/value for Servicescape development.

\section{Conflicts of Interest}

The authors declare no conflicts of interest regarding the publication of this paper.

\section{References}

Aubert-Gamet, V. (1997). Twisting Servicescapes: Diversion of the Physical Environment in a Re-Appropriation Process. International Journal of Service Industry Management, 8, 26-41. https://doi.org/10.1108/09564239710161060

Baker, D. A., \& Crompton, J. L. (2000). Quality, Satisfaction and Behavioral Intentions. Annals of Tourism Research, 27, 785-804. https://doi.org/10.1016/S0160-7383(99)00108-5

Baker, J., \& Cameron, M. (1996). The Effects of the Service Environment on Affect and Consumer Perception of Waiting Time: An Integrative Review and Research Propositions. Journal of the Academy of Marketing Science, 24, 338-349.

https://doi.org/10.1177/0092070396244005

Berry, L. L., Wall, E. A., \& Carbone, L. P. (2006). Service Clues and Customer Assessment of the Service Experience: Lessons from Marketing. Academy of Management Perspectives, 20, 43-57. https://doi.org/10.5465/amp.2006.20591004

Berry, L., Carbone, L., \& Haeckel, S. (2002). Managing the Total Customer Experience Managing the Total Customer Experience. MIT Sloan Management Review, 43, 114-137.

Bitner, M. J. (1990). Evaluating Service Encounters: The Effects of Physical Surroundings and Employee Responses. Journal of Marketing, 54, 69-82. https://doi.org/10.1177/002224299005400206

Bitner, M. J. (1992). Servicescapes: The Impact of Physical Surroundings on Customers and Employees. Journal of Marketing, 56, 57-71. https://doi.org/10.1177/002224299205600205

Carbone, L. P., \& Haeckel, S. H. (1994). Engineering Customer Experiences. Marketing Management, 3, 8-19.

Carmer, J. C., \& Rouzer, D. L. (1974). Healthy Functioning from the Gestalt Perspective. The Counseling Psychologist, 4, 20-23. https://doi.org/10.1177/001100007400400408

Chan, S. H. J., Wan, Y. K. P., \& Tam, U. T. Z. (2019). Tourists' Description of their Experiences of the Servicescape of Integrated Resorts: The Case of Macau. International Journal of Hospitality \& Tourism Administration, 1-34. https://doi.org/10.1080/15256480.2019.1641453

Chua, B. L., Othman, M., Boo, H. C., Abkarim, M. S., \& Ramachandran, S. (2010). Servicescape Failure and Recovery Strategy in the Food Service Industry: The Effect on Customer Repatronization. Journal of Quality Assurance in Hospitality \& Tourism, 11, 179-198. https://doi.org/10.1080/1528008X.2010.483419

Clark, M. A., \& Wood, R. C. (1998). Consumer Loyalty in the Restaurant Industry: A Pre- 
liminary Exploration of the Issues. International Journal of Contemporary Hospitality Management. https://doi.org/10.1108/09596119810222104

Clydesdale, F. M., Gover, R., \& Fugardi, C. (1992). The Effect of Color on Thirst Quenching, Sweetness, Acceptability and Flavor Intensity in Fruit Punch Flavored Beverages. Journal of Food Quality, 15, 19-38. https://doi.org/10.1111/j.1745-4557.1992.tb00973.x

Creswell, J. W. (2013). Qualitative Inquiry and Research Design: Choosing Among Five Approaches. SAGE.

Crouch, M., \& McKenzie, H. (2006). The Logic of Small Samples in Interview-Based Qualitative Research. Social Science Information, 45, 483-499. https://doi.org/10.1177/0539018406069584

Crowley, A. E. (1993). The Two Dimensional Impact of Color on Shopping. Marketing Letters, 4, 59-69. https://doi.org/10.1007/BF00994188

Duncan, H. J. (1996). Effects of Music in Service Environments: A Field Study. Journal of Services Marketing, 10, 26-41. https://doi.org/10.1108/08876049610114249

Gorn, G. J., Chattopadhyay, A., Yi, T., \& Dahl, D. W. (1997). Effects of Color as an Executional Cue in Advertising: They're in the Shade. Management Science, 43, 1387-1400. https://doi.org/10.1287/mnsc.43.10.1387

Ha, J., \& Jang, S. S. (2012). The Effects of Dining Atmospherics on Behavioral Intentions through Quality Perception. Journal of Services Marketing. https://doi.org/10.1300/J150v15n03_02

Han, H., \& Back, K.-J. (2007). Investigating the Effects of Consumption Emotions on Customer Satisfaction and Repeat Visit Intentions in the Lodging Industry. Journal of Hospitality \& Leisure Marketing, 15, 5-30. https://doi.org/10.1300/J150v15n03_02

Harrell, G. D., Hutt, M. D., \& Anderson, J. C. (1980). Path Analysis of Buyer Behavior under Conditions of Crowding. Journal of Marketing Research, 17, 45-51. https://doi.org/10.1177/002224378001700105

Harris, L. C., \& Ezeh, C. (2008). Servicescape and Loyalty Intentions: An Empirical Investigation. European Journal of Marketing, 42, 390-422. https://doi.org/10.1108/03090560810852995

Heskett, J. L., Jones, T. O., Loveman, G. W., Sasser, W. E., \& Schlesinger, L. A. (1994). Putting the Service Profit Chain to Work. Harvard Business Review, 72, 164-174.

Hightower, R. (2003). Framework for Managing the Servicescape: A Sustainable Competitive Advantage. Marketing Management Journal, 13, 84-95.

Hirshman, E., \& Holbrook, M. (1992). Postmodern Consumer Research: The Study of Consumption as Text. https://doi.org/10.4135/9781483325941

Ho, Y., Lam, L. W., \& Lam, D. (2019). Gamble More than You Want? A Study of Casino Servicescape, Perceived Control and Unplanned Gaming Behaviors. International Journal of Contemporary Hospitality Management, 31, 557-574. https://doi.org/10.1108/IJCHM-10-2017-0679

Hoch, S. J., \& Deighton, J. (1989). Managing What Consumers Learn from Experience. Journal of Marketing, 53, 1-20. https://doi.org/10.1177/002224298905300201

Holbrook, M. B., \& Anand, P. (1990). Effects of Tempo and Situational Arousal on the Listener's Perceptual and Affective Responses to Music. Psychology of Music, 18, 150-162. https://doi.org/10.1177/0305735690182004

Hutton, J. D., \& Richardson, L. D. (1995). Healthscapes: The Role of the Facility and Physical Environment on Consumer Attitudes, Satisfaction, Quality Assessments, and Behaviors. Health Care Management Review, 20, 48-61. 
https://doi.org/10.1097/00004010-199502020-00008

Johnson, R. (1991). A Strategy for Service-Disney Style. Journal of Business Strategy, 12, 38-43. https://doi.org/10.1108/eb039442

Keaveney, S. M. (1995). Customer Switching Behavior in Service Industries: An Exploratory Study. Journal of Marketing, 59, 71. https://doi.org/10.2307/1252074

Kim, W. (2009). Customers' Responses to Customer Orientation of Service Employees in Full-Service Restaurants: A Relational Benefits Perspective. Journal of Quality Assurance in Hospitality \& Tourism, 10, 153-174. https://doi.org/10.1080/15280080902988188

Kim, W., \& Moon, Y. (2009). Customers' Cognitive, Emotional, and Actionable Response to the Servicescape: A Test of the Moderating Effect of the Restaurant Type. International Journal of Hospitality Management, 28, 144-156. https://doi.org/10.1016/j.ijhm.2008.06.010

Kim, Y. H., Duncan, J., \& Chung, B. W. (2015). Involvement, Satisfaction, Perceived Value, and Revisit Intention: A Case Study of a Food Festival. Journal of culinary science \& technology, 13, 133-158. https://doi.org/10.1080/15428052.2014.952482

Lam, L. W., Chan, K. W., Fong, D., \& Lo, F. (2011). Does the Look Matter? The Impact of Casino Servicescape on Gaming Customer Satisfaction, Intention to Revisit, and Desire to Stay. International Journal of Hospitality Management, 30, 558-567.

https://doi.org/10.1016/j.ijhm.2010.10.003

Lin, I. Y. (2004). Evaluating a Servicescape: The Effect of Cognition and Emotion. International Journal of Hospitality Management, 23, 163-178.

https://doi.org/10.1016/j.ijhm.2003.01.001

Lin, I. Y., \& Mattila, A. S. (2010). Restaurant Servicescape, Service Encounter, and Perceived Congruency on Customers' Emotions and Satisfaction. Journal of Hospitality Marketing \& Management, 19, 819-841. https://doi.org/10.1080/19368623.2010.514547

Lockwood, A. (1994). Using Service Incidents to Identify Quality Improvement Points. International Journal of Contemporary Hospitality Management, 6, 75-80. https://doi.org/10.1108/09596119410052170

Lovelock, C., \& Wirtz, J. (2007). Services Marketing: People, Technology, Strategy (6th ed.). Upper Saddle River: Pearson Prentice Hall.

Macao Statistic and Census Services (2018). Survey on Manpower Needs and Wages Manufactures, Hotels, Restaurants, Insurance, Financial, Intermediation Activities, Child-Care, Elderly Care. 3rd Quarter, 2018.

https://www.dsec.gov.mo/Statistic.aspx?lang=en-US\&NodeGuid=b973199f-f3e1-42e3bfd8-9e4498787954

MacLaurin, D. J., \& MacLaurin, T. L. (2000). Customer Perceptions of Singapore's Theme Restaurants. Cornell Hotel and Restaurant Administration Quarterly, 41, 75-85. https://doi.org/10.1177/001088040004100319

Marković, S., Raspor, S., \& Šegarić, K. (2010). Does Restaurant Performance Meet Customers' Expectations? An Assessment of Restaurant Service Quality Using a Modified DINESERV Approach. Tourism and Hospitality Management, 16, 181-195.

Mathur, T., \& Gupta, A. (2019). Impact of "Dining Atmospherics" and "Percived Food-Quality" on Customer Re-Patronage Intention in Fast-Casual Restaurants. Tourism and Hospitality Management, 25, 1-25. https://doi.org/10.20867/thm.25.1.6

Mattila, A. S. (2001). Emotional Bonding and Restaurant Loyalty. Cornell Hotel and Restaurant Administration Quarterly, 42, 73-79. 
https://doi.org/10.1016/S0010-8804(01)81012-0

Mehrabian, A., \& Russell, J. A. (1974). An Approach to Environmental Psychology. Cambridge, MA, US: The MIT Press.

Miller, J. L., Craighead, C. W., \& Karwan, K. R. (2000). Service Recovery: A Framework and Empirical Investigation. Journal of Operations Management, 18, 387-400. https://doi.org/10.1016/S0272-6963(00)00032-2

Milliman, R. E. (1982). Using Background Music to Affect the Behavior of Supermarket Shoppers. Journal of Marketing, 46, 86-91. https://doi.org/10.1177/002224298204600313

Milliman, R. E. (1986) The Influence of Background Music on the Behavior of Restaurant Patrons. Journal of Consumer Research, 13, 286-289. https://doi.org/10.1086/209068

Mohsin, A., McIntosh, A., \& Cave, J. (2007). Expectations of the Service Experience Offered by Restaurants and Cafes in Hamilton, New Zealand. Journal of Hospitality and Tourism Management, 12, 108-117.

Namkung, Y., \& Jang, S. (2007). Does Food Quality Really Matter in Restaurants? Its Impact on Customer Satisfaction and Behavioral Intentions. Journal of Hospitality \& Tourism Research, 31, 387-409. https://doi.org/10.1177/1096348007299924

Nevin, F. (1991). Office Chairs Are an Investment in People: Firms Vying for New Employees Must Consider Their Health and Comfort. The Office, 16, 48-49.

Parish, J. T., Berry, L. L., \& Shun Yin Lam. (2008). The Effect of the Servicescape on Service Workers. Journal of Service Research, 10, 220-238. https://doi.org/10.1177/1094670507310770

Patton, M. Q. (2005). Qualitative Research. In B. S. Everitt \& D. C. Howell (Eds.), Encyclopedia of Statistics in Behavioral Science (p. bsa514). Hoboken: John Wiley \& Sons, Ltd. https://doi.org/10.1002/0470013192.bsa514

Pivac, T., Blesic, I., Stamenkovic, I., \& Besermenji, S. (2011). Event Management and Consumer Satisfaction in Tourism Industry. African Journal of Business Management, 5, 13240. https://doi.org/10.5897/AJBM11.1641

Pizam, A. (1999). Cross-Cultural Tourist Behavior. Consumer Behavior in Travel and Tourism, 17, 393-411.

Rohner, S. J., \& Miller, R. (1980). Degrees of Familiar and Affective Music and Their Effects on State Anxiety. Journal of Music Therapy, 17, 2-15.

https://doi.org/10.1093/jmt/17.1.2

Ryu, K., \& Han, H. (2010). Influence of the Quality of Food, Service, and Physical Environment on Customer Satisfaction and Behavioral Intention in Quick-Casual Restaurants: Moderating Role of Perceived Price. Journal of Hospitality \& Tourism Research, 34, 310-329. https://doi.org/10.1177/1096348009350624

Ryu, K., \& Han, H. (2011). New or Repeat Customers: How Does Physical Environment Influence Their Restaurant Experience? International Journal of Hospitality Management, 30, 599-611. https://doi.org/10.1016/j.ijhm.2010.11.004

Ryu, K., \& Jang, S. (2008). Influence of Restaurants' Physical Environments on Emotion and Behavioral Intention. The Service Industries Journal, 28, 1151-1165. https://doi.org/10.1080/02642060802188023

Ryu, K., \& Jang, S. S. (2007). The Effect of Environmental Perceptions on Behavioral Intentions through Emotions: The Case of Upscale Restaurants. Journal of Hospitality \& Tourism Research, 31, 56-72. https://doi.org/10.1177/1096348006295506

Schiffman, H. R. (2001). Sensation and Perception: An Integrated Approach (5th ed). New York: Wiley. 
Shiffman, L. G., \& Kanuk, L. L. (1978). Consumer Behavior (1st ed).

Siu, N. Y.-M., Wan, P. Y. K., \& Dong, P. (2012). The Impact of the Servicescape on the Desire to Stay in Convention and Exhibition Centers: The Case of Macao. International Journal of Hospitality Management, 31, 236-246. https://doi.org/10.1016/j.ijhm.2011.06.011

Smith, P. C., \& Curnow, R. (1966). “Arousal Hypothesis” and the Effects of Music on Purchasing Behavior. Journal of Applied Psychology, 50, 255-256. https://doi.org/10.1037/h0023326

Sulek, J. M., \& Hensley, R. L. (2004). The Relative Importance of Food, Atmosphere, and Fairness of Wait: The Case of a Full-Service Restaurant. Cornell Hotel and Restaurant Administration Quarterly, 45, 235-247. https://doi.org/10.1177/0010880404265345

Sullivan, M. (2002). The Impact of Pitch, Volume and Tempo on the Atmospheric Effects of Music. International Journal of Retail \& Distribution Management, 30, 323-330. https://doi.org/10.1108/09590550210429531

Szymanski, D. M., \& Henard, D. H. (2001). Customer Satisfaction: A Meta-Analysis of the Empirical Evidence. Journal of the Academy of Marketing Science, 29, 16-35. https://doi.org/10.1177/0092070301291002

Thomson, S. B. (2010). Sample Size and Grounded Theory. Thomson, SB (2010). Grounded Theory-Sample Size. Journal of Administration and Governance, 5, 45-52.

Um, S., Chon, K., \& Ro, Y. (2006). Antecedents of Revisit Intention. Annals of Tourism Research, 33, 1141-1158. https://doi.org/10.1016/j.annals.2006.06.003

Vong, L. T.-N., \& Ung, A. (2012). Exploring Critical Factors of Macau's Heritage Tourism: What Heritage Tourists are Looking for when Visiting the City's Iconic Heritage Sites. Asia Pacific Journal of Tourism Research, 17, 231-245. https://doi.org/10.1080/10941665.2011.625431

Wada, Y., Arce-Lopera, C., Masuda, T., Kimura, A., Dan, I., Goto, S. I., \& Okajima, K. (2010). Influence of Luminance Distribution on the Appetizingly Fresh Appearance of Cabbage. Appetite, 54, 363-368. https://doi.org/10.1016/j.appet.2010.01.002

Wai Lai, I. K. (2019). Hotel Image and Reputation on Building Customer Loyalty: An Empirical Study in Macau. Journal of Hospitality and Tourism Management, 38, 111-121. https://doi.org/10.1016/j.jhtm.2019.01.003

Wakefield, K. L., \& Blodgett, J. G. (1996). The Effect of the Servicescape on Customers' Behavioral Intentions in Leisure Service Settings. Journal of Services Marketing, 10, 45-61. https://doi.org/10.1108/08876049610148594

Wakefield, K. L., \& Blodgett, J. G. (1999). Customer Response to Intangible and Tangible Service Factors. Psychology and Marketing, 16, 51-68. https://doi.org/10.1002/(SICI)1520-6793(199901)16:1<51::AID-MAR4>3.0.CO;2-0a

Wakefield, K. L., Blodgett, J. G., \& Sloan, H. J. (1996). Measurement and Management of the Sportscape. Journal of Sport Management, 10, 15-31. https://doi.org/10.1123/jsm.10.1.15

Wakefield, L. K., \& Blodgett, G. J. (1994). The Importance of Servicescapes in Leisure Service Settings. Journal of Services Marketing, 8, 66-76. https://doi.org/10.1108/08876049410065624

Wall, E. A., \& Berry, L. L. (2007). The Combined Effects of the Physical Environment and Employee Behavior on Customer Perception of Restaurant Service Quality. Cornell Hotel and Restaurant Administration Quarterly, 48, 59-69. https://doi.org/10.1177/0010880406297246

Wang, C.-Y., \& Mattila, A. S. (2015). The Impact of Servicescape Cues on Consumer 
Prepurchase Authenticity Assessment and Patronage Intentions to Ethnic Restaurants. Journal of Hospitality \& Tourism Research, 39, 346-372. https://doi.org/10.1177/1096348013491600

Wirtz, J., \& Bateson, J. E. G. (1995). An Experimental Investigation of Halo Effects in Satisfaction Measures of Service Attributes. International Journal of Service Industry Management, 6, 84-102. https://doi.org/10.1108/09564239510091358

Wirtz, J., Mattila, A. S., \& Tan, R. L. P. (2000). The Moderating Role of Target-Arousal on the Impact of Affect on Satisfaction-An Examination in the Context of Service Experiences. Journal of Retailing, 76, 347-365.

https://doi.org/10.1016/S0022-4359(00)00031-2

Yu, C.-E., \& Sun, R. (2019). The role of Instagram in the UNESCO's creative city of gastronomy: A case study of Macau. Tourism Management, 75, 257-268.

https://doi.org/10.1016/j.tourman.2019.05.011

Zeithaml, V. A., \& Bitner, M.J. (2003). Services Marketing: Integrating Customer Focus across the Firm. McGraw-Hill.

Zeithaml, V. A., Bitner, M. J., \& Gremler, D. D. (2009). Services Marketing: Integrating Customer Focus across the Firm. New York: McGraw-Hill/Irwin.

Zellner, D. A., \& Durlach, P. (2002). What Is Refreshing? An Investigation of the Color and Other Sensory Attributes of Refreshing Foods and Beverages. Appetite, 39, 185-186. https://doi.org/10.1006/appe.2002.0502

Zellner, D. A., \& Durlach, P. (2003). Effect of Color on Expected and Experienced Refreshment, Intensity, and Liking of Beverages. The American Journal of Psychology, 116, 633. https://doi.org/10.2307/1423663

Zins, A. H. (2002). Consumption Emotions, Experience Quality and Satisfaction: A Structural Analysis for Complainers versus Non-Complainers. Journal of Travel \& Tourism Marketing, 12, 3-18. https://doi.org/10.1300/J073v12n02_02 